\title{
KAJIAN SISTEM AGRIBISNIS PAKCOY ORGANIK: KASUS PADA POKTAN SAUNG ORGANIK
}

\section{THE STUDY OF THE ORGANIC PAKCOY AGRIBUSINESS SYSTEM: THE CASE OF THE ORGANIC SAUNG FARMING GROUP}

\section{Elly Rasmikayati ${ }^{1}$, Mufti Helmi ${ }^{1}$, Hesty Nurul Utami ${ }^{1}$, Gunardi Judawinata ${ }^{1}$, Bobby Rachmat Saefudin*2}

\author{
${ }^{1}$ Fakultas Pertanian, Universitas Padjadjaran, Jl. Ry Bandung-Sumedang KM.21 Jatinangor, 45363 \\ ${ }^{2}$ Fakultas Pertanian, Ma'soem University, Jl. Raya Cipacing No. 22 Jatinangor, 45363 \\ *E-mail: bobbyrachmat@masoemuniversity.ac.id \\ (Diterima 10-1-2021; Disetujui 18-1-2021)
}

\begin{abstract}
ABSTRAK
Kelompok tani Saung Organik merupakan produsen produk sayuran organik telah mendapatkan Sertifikat Pangan Organik dari Indonesian Organic Farming Certification (Inofice) pada tahun 2013 untuk jenis sayuran daun diantaranya pakcoy. Penelitian ini bertujuan untuk mengkaji sistem agribisnis pada usahatani pakcoy organik yang dilakukan Kelompok tani Saung Organik. Penelitian ini menggunakan desain kualitatif dengan pendekatan metode studi kasus. Rancangan analisis data menggunakan analisis deskriptif. Hasil penelitian menggambarkan bahwa pada subsistem hulu usahatani pakcoy organik, pengadaan sarana produksi meliputi mobil pick up untuk transportasi, cangkul, kored, sprayer, pupuk kandang, pupuk cair organik, benih pakcoy gardena, sumur bor untuk memenuhi ketersediaan air, tricoderma, dan kemasan serta tali ikat. Faktor produksi usahatani pakcoy organik meliputi luas penguasaan lahan di dalam kelompok adalah 0,5 hektar, tidak memakai tenaga kerja di luar anggota kelompok tani, dan jumlah modal yang dimiliki adalah Rp 3.690.744. Pada subsistem produksi, proses budidaya pakcoy organik dilakukan dengan sistem pola tanam 15 hari sekali, dan ditanam secara monokultur. Sementara pada subsistem panen dan pasca panen, umur panen tanaman pakcoy organik adalah 30-33 hari. Dalam 1 tahun terdapat 12 kali musim tanam dan panen. Produksi pakcoy organik mencapai $1.434 \mathrm{~kg} / \mathrm{musim}$ tanam. Proses pascapanen meliputi pencucian, penyortiran, penimbangan, dan pengemasan. Dalam pemasaran, konsumen yang datang langsung ke kelompok tani untuk mengambil pesanan.
\end{abstract}

Kata kunci: sistem, subsistem, agribisnis, pakcoy, organik, kelompok tani, hulu, produksi, hilir

\begin{abstract}
The Saung Organic farmer group is a producer of organic vegetable products that has received an Organic Food Certificate from the Indonesian Organic Farming (Inofice) Certification in 2013 for the types of leafy vegetables including pakcoy. This study aims to examine the agribusiness system in organic pakcoy farming carried out by the Organic Saung Farmer Group. This study used a qualitative design with a case study method approach. The data analysis design used descriptive analysis. The results illustrate that in the upstream organic pakcoy subsystem, the procurement of production facilities includes pick-ups car, hoes, cored, sprayers, manure, organic liquid fertilizer, pakcoy gardena seeds, drilling wells to meet water availability, tricoderma, and packaging as well as tie rope. The production factor for organic pakcoy farming includes the area of land ownership in the group which is 0.5 hectares, does not use labor outside the farmer group members, and the amount of capital owned is Rp. 3,690,744. In the production subsystem, the organic pakcoy cultivation process is carried out with a cropping system system once every 15 days and planted in monoculture. Meanwhile, in the harvest and post-harvest subsystems, the harvest age for organic pakcoy plants is 30-33 days. In 1 year there are 12 planting and harvesting seasons. Organic pakcoy production reaches $1,434 \mathrm{~kg} /$ planting season. The post-harvest process includes washing, sorting, weighing and packaging. In marketing, consumers come directly to farmer groups to take orders.
\end{abstract}


Keywords: system, subsystem, agribusiness, pakcoy, organic, farmer groups, upstream, on farm, downstream

\section{PENDAHULUAN}

Gaya hidup sehat atau lebih dikenal dengan slogan "back to nature" di zaman modern seperti sekarang semakin banyak dilakukan. Banyak masyarakat yang telah menyadari pentingnya kesehatan dengan mengurangi konsumsi bahan makanan yang berbahaya bagi tubuh, khususnya sayuran yang banyak mengandung bahan kimia, seperti sayur-sayuran yang mengandung pestisida kimia berbahaya (Manuhutu, 2005). Penggunaan bahan kimia ini tidak hanya membahayakan bagi kesehatan tubuh manusia, tapi juga berdampak buruk bagi lingkungan. Slogan "back to nature" inilah yang terus mendorong masyarakat untuk memilih produk-produk organik, khususnya sayuran organik (Rasmikayati dkk., 2019).

Pemerintah melalui Direktorat Pengolahan dan Pemasaran Hasil Pertanian telah memprakarsai program "Go Organik 2010" yang telah dikembangkan sejak tahun 2001 sehingga mendukung kesadaran untuk "back to nature" di sektor pertanian (Rasmikayati dkk., 2020). Misi yang diemban dalam Program “Go Organik 2010” adalah "Meningkatkan mutu hidup masyarakat dan kelestarian lingkungan alam Indonesia, dengan mendorong berkembangnya pertanian organik yang berdaya saing dan berkelanjutan" (Sari dkk., 2020).

Jawa Barat yang selama ini lebih dikenal sebagai lumbung padi, juga merupakan sentra sayuran di Indonesia, khususnya di pulau Jawa. Pada tahun 2014, Jawa Barat merupakan provinsi penghasil sayuran tertinggi di Indonesia yaitu sebesar 2.762.021 ton (Kementerian Pertanian, 2014). Potensi luas panen sayuran di Jawa Barat lebih terkonsentrasi pada beberapa daerah. Konsentrasi luas panen sayuran dengan pangsa $>10 \%$ terdapat di kabupaten Bandung dan Garut (sayuran dataran tinggi) serta bekasi (dataran rendah), Sumedang (tinggi dan rendah) (Rachmat, 2013). Sehingga tidak salah jika sayuran menjadi salah satu komoditas andalan kabupaten Garut, baik itu sayuran organik ataupun non-organik.

Terdapat 42 kecamatan di kabupaten Garut, beberapa kecamatan telah merintis pola pertanian organik dengan komoditas sayuran daun, salahsatunya adalah kecamatan Balubur Limbangan. Terdapat satu Kelompok 
Tani yang telah merintis pertanian organik di kecamatan Balubur Limbangan, yaitu Kelompok tani Saung Organik yang telah didirikan pada tahun 2012. Kelompok tani Saung Organik ini merupakan kelompok tani yang didirikan secara pribadi oleh anggota-anggotanya. Kelompok tani Saung Organik telah mendapatkan Sertifikat Pangan Organik dari Indonesian Organic Farming Certification (Inofice) pada tahun 2013. Produk sayuran organik yang telah dibudidayakan dan mendapat sertifikasi organik antara lain jenis sayuran daun yaitu Saosin, Pakcoy, dan Kaylan. Di Kecamatan Balubur Limbangan, pertanian sayuran organik didukung dengan tersedianya pupuk kandang yang berlimpah, karena Kecamatan Balubur Limbangan merupakan kecamatan dengan populasi sapi potong terbanyak di kabupaten Garut, sehingga tidak terkendala ketersediaan pupuk kandang.

Berdasarkan latar belakang tersebut, menarik untuk mengkaji lebih dalam mengenai budidaya pakcoy organik ini. Penelitian ini bertujuan untuk mengkaji sistem agribisnis pada usahatani pakcoy organik yang dilakukan Kelompok tani Saung Organik.

\section{METODE PENELITIAN}

Objek dan Tempat Penelitian

Objek yang menjadi fokus penelitian ini adalah sistem agribisnis usahatani pakcoy organik. Penelitian dilakukan di kelompok tani Saung Organik yang produk pakcoy organiknya telah tersertifikasi organik oleh badan sertifikasi organik Inoffice.

\section{Desain Penelitian}

Penelitian ini menggunakan desain kualitatif. Pendekatan kualitatif dipilih karena dalam penelitian ini sasaran atau objek penelitian tidak dibatasi agar datadata yang diambil dapat digali sebanyak mungkin. Metode yang digunakan pada penelitian adalah metode studi kasus. Yin (2013) menjelaskan bahwa objek yang dapat diangkat dalam studi kasus adalah sesuatu yang merupakan kejadian yang sedang berlangsung atau telah berlangsung, tetapi masih menyisakan dampak dan pengaruh yang luas, kuat atau khusus pada saat penelitian dilakukan.

\section{Variabel Penelitian}

Sistem agribisnis Pakcoy Organik meliputi beberapa subsistem diantarnya:

a. Subsistem hulu yang terdiri atas pengadaan sarana produksi faktor- 
faktor produksi usahatan. Pengadaan sarana produksi yaitu segala sesuatu yang dibutuhkan dalam satu kali proses produksi, meliputi peralatan, bibit, dan pupuk. Faktor-faktor produksi usahatani dalam upaya pemenuhan permintaan pakcoy organik terdiri atas tanah, tenaga kerja, dan modal.

b. Subsistem produksi yaitu proses budi daya dalam usaha tani pakcoy organik yaitu mulai dari persiapan lahan, pengolahan tanah, penanaman, dan pemeliharaan.

c. Subsistem panen dan pascapanen. Panen adalah proses pencabutan seluruh tanaman beserta akarnya. Pascapanen adalah proses setelah panen seperti sortasi, pengepakan, pembungkusan, penyimpanan dan pemasaran.

\section{Jenis dan Sumber Data}

Data yang dikumpulkan dalam penelitian ini berasal dari dua sumber data/informasi, yaitu data primer dan data sekunder.

\section{Data primer}

Data primer adalah data yang diperoleh secara langsung dari sumber utama, sumber data yang diperoleh dan dikumpulkan dari pengamatan langsung (observasi) dan wawancara secara mendalam. Sumber data diperoleh dari informan yang dipilih secara purposive. Informan adalah orang yang dipandang mengetahui permasalahan yang akan dikaji dan bersedia memberikan informasi kepada peneliti. Informan dalam penelitian ini yaitu:

a. Ketua kelompok tani Saung Organik

b. Anggota kelompok tani Saung Organik yang melakukan usahatani pakcoy organik yang berjumlah 6 orang.

2. Data sekunder, yaitu data/informasi yang berupa literatur yang relevan dengan penelitian, atau data yang menunjang penelitian. Data sekunder bisa diperoleh dari dalam ataupun luar kelompok tani. Sumber data sekunder di luar kelompok tani berasal dari instansi-instansi terkait seperti BPS, Dinas Pertanian, dan lain sebagainya.

\section{Rancangan Analisis Data}

Penelitian ini menggunakan rancangan analisis deskriptif. Analisis deskriptif dilakukan dengan cara menggambarkan secara rinci data yang diperoleh dengan membuat tabulasi hasil jawaban responden lalu dipresentasikan. Metode ini dilakukan melalui beberapa tahap, yaitu melakukan wawancara 
terhadap informan, mentabulasikan semua jawaban informan berdasarkan hasil wawancara, dan melakukan analisis berdasarkan hasil yang diperoleh dari pentabulasian.

\section{HASIL DAN PEMBAHASAN}

Deskripsi Sistem Agribisnis Usahatani Pakcoy Organik di Kelompok Tani Saung Organik, Desa Pasirwaru, Kecamatan Balubur Limbangan, Kabupaten Garut

\section{Subsistem Hulu}

\section{A. Pengadaan Sarana Produksi}

Sarana produksi merupakan kelengkapan atau sarana yang mendukung kegiatan produksi disuatu perusahaan (Rasmikayati dkk., 2020). Pengadaan sarana produksi dalam pertanian organik meliputi benih, peralatan, ketersediaan air, ketersediaan transportasi, pestisida nabati, dan pupuk.

Kelompok Tani Saung Organik usahataninya dilengkapi dengan ketersediaan air yang cukup untuk memenuhi kebutuhan kelompok tani dalam produksi. Kelompok Tani Saung Organik memiliki sumber air sendiri yaitu sumur bor yang terletak di salah satu lahan informan, airnya digunakan untuk memenuhi kebutuhan dalam proses penyiraman dan pengairan. Cara pendistribusian air ke lahan informan yang lain adalah dengan menggunakan pipa air/selang.

Saat ini sarana transportasi yang dimiliki Kelompok Tani Saung Organik adalah satu mobil operasional dengan alasan ekonomis, dapat menampung banyak produk dan praktis. Mobil yang digunakan adalah jenis mobil pick-up.

1. Pengadaan Pupuk

Budidaya Pakcoy Organik di Kelompok Tani Saung Organik menggunakan dua jenis pupuk, yaitu pupuk kandang dan pupuk cair organik. Pupuk kandang diperoleh dari peternakan desa sekitar. Sedangkan pupuk cair organik diperoleh dari toko penyedia sarana pertanian yang berada di Kecamatan Balubur Limbangan. Pupuk kandang yang dipakai dalam satu musim tanam yaitu kotoran sapi. Pupuk kotoran sapi ini sangat baik dalam mengoptimalkan produksi (Muchtar, 2020). Rincian untuk penggunaan pupuk kandang dan pupuk cair organik dapat dilihat pada Tabel 1.

Tabel 1. Penggunaan Pupuk Kandang dan Pupuk Organik Cair (POC) Per Musim Tanam

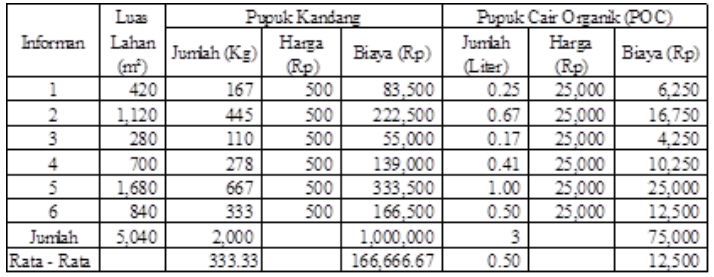


Berdasarkan Tabel 1 dapat dilihat bahwa jumlah pupuk kandang dan pupuk cair organik yang digunakan untuk produksi Pakcoy Organik permusim tanam tiap informan berbeda tergantung luas lahan yang digarap. Semakin luas lahan yang digarap, semakin besar kebutuhan pupuknya.

2. Pengadaan Tricoderma

Jika terserang penyakit maka informan di Kelompok Tani Saung Organik menggunakan Tricoderma (agen hayati). Tricoderma digunakan dengan cara dicampur dengan air dan langsung disemprot ke tanaman yang terserang penyakit. Tricoderma diperoleh dari toko penyedia sarana pertanian yang berada di Kecamatan Balubur Limbangan. Rincian untuk penggunaan Tricoderma di Kelompok Tani Saung Organik dapat dilihat pada Tabel 2.

Tabel 2. Penggunaan Tricoderma Per Musim Tanam

\begin{tabular}{|c|r|r|r|r|}
\hline Informan & Luas Lahan & Jumlah (Liter) & Harga (Rp) & \multicolumn{1}{c|}{ Biaya } \\
\hline 1 & 420 & 0.25 & 20,000 & 5,000 \\
\hline 2 & 1,120 & 0.67 & 20,000 & 13,400 \\
\hline 3 & 280 & 0.17 & 20,000 & 3,400 \\
\hline 4 & 700 & 0.41 & 20,000 & 8,200 \\
\hline 5 & 1,680 & 1.00 & 20,000 & 20,000 \\
\hline 6 & 840 & 0.50 & 20,000 & 10,000 \\
\hline Jumlah & 5,040 & 3 & & 60,000 \\
\hline Rata - Rata & & 0.50 & & 10,000 \\
\hline
\end{tabular}

Berdasarkan Tabel 2 dapat disimpulkan bahwa jumlah Tricoderma yang digunakan untuk produksi Pakcoy Organik per musim tanam tiap informan berbeda tergantung luas lahan yang digarap. Semakin luas lahan yang digarap, semakin besar kebutuhan Tricodermanya. Jumlah total Tricoderma yang digunakan dengan luas lahan 0,5 hektar dalam satu musim tanam adalah 3 liter dengan harga Rp 20.000 perliter dan total biaya yang dikeluarkan adalah $\mathrm{Rp}$ 60.000/musim tanam.

\section{Pengadaan Benih}

Pakcoy Organik di Kelompok Tani Saung Organik dibudidayakan dengan menggunakan benih yang didapatkan di toko-toko yang ada di pasaran. Pembelian benih di pasaran masih diperbolehkan, asalkan benih tersebut bukan berasal dari hasil rekayasa genetika (Genetic Modified Organism atau GMO). Pemilihan benih harus sesuai dengan aturan yang telah ditentukan dalam SNI 01-6729-2013. Merk benih yang digunakan adalah Gardena yang dibeli di toko penyedia sarana pertanian yang berada di Kecamatan Balubur Limbangan, dengan harga Rp 25.000 per amplop dengan berat bersih 15 gram. Menurut informan, Benih merk Gardena dipilih karena mudah didapat, kualitasnya sangat baik, dan hasil yang diperoleh dari hasil panen memiliki kualitas yang baik untuk dipasarkan. 
Kebutuhan benih dalam satu kali musim tanam untuk luasan lahan produksi di Kelompok Tani Saung Organik adalah 15 amplop atau 225 gram dengan harga pergramnya adalah $\mathrm{Rp}$ 1.667 /gram dan biaya total yang dikeluarkan adalah Rp 375.075/musim tanam. Untuk rincian kebutuhan benih peranggotanya dapat dilihat pada Tabel 3.

Tabel 3. Penggunaan Benih Per Musim Tanam

\begin{tabular}{|c|r|r|r|r|}
\hline Informan & Luas Lahan $\left(\mathrm{m}^{2}\right)$ & Jumlah (gram) & Harga & \multicolumn{1}{c|}{ Biaya } \\
\hline 1 & 420 & 18.75 & 1,667 & 31,256 \\
\hline 2 & 1,120 & 50.00 & 1,667 & 83,350 \\
\hline 3 & 280 & 12.50 & 1,667 & 20,838 \\
\hline 4 & 700 & 31.25 & 1,667 & 52,094 \\
\hline 5 & 1,680 & 75.00 & 1,667 & 125,025 \\
\hline 6 & 840 & 37.50 & 1,667 & 62,513 \\
\hline Juniah & 5,040 & 225.00 & & 375,075 \\
\hline Rata - Rata & & 37.50 & & $62,512.50$ \\
\hline
\end{tabular}

\section{Pengadaan Peralatan}

Peralatan yang dibutuhkan dalam kegiatan produksi Pakcoy Organik sama dengan peralatan yang digunakan oleh petani lain dalam proses produksi usahatani. Peralatan yang dibutuhkan antara lain: cangkul, kored, dan sprayer. Untuk harga cangkul adalah 45.000/unit, kored seharga 15.000/unit, dan sprayer dengan harga Rp 500.000/unit. Untuk kebutuhan cangkul dan kored produksi Pakcoy Organik di Kelompok Tani Saung Organik adalah 6 unit dengan umur ekonomis selama 2 tahun. Setiap informan memakai 1 unit cangkul, tidak dipengaruhi oleh luas lahan. Sedangkan untuk sprayer, Kelompok Tani Saung
Organik menyediakan 1 unit untuk pemakaian secara bersama dengan umur ekonomis selama 5 tahun dengan biaya penyusutannya adalah Rp 8.330/musim tanam. Sedangkan biaya penyusutan untuk 1 unit cangkul adalah $\mathrm{Rp}$ 1.875/musim tanam, dan biaya penyusutan untuk kored adalah $\mathrm{Rp}$ 625/musim tanam.

Dengan demikian, biaya total untuk peralatan permusim tanam di Kelompok Tani Saung Organik adalah Rp $860.000 /$ musim tanam dan total biaya penyusutannya adalah Rp 23.330/musim tanam. Untuk rincian pengadaan perlatannya dapat dilihat pada Tabel 4 .

Tabel 4. Pengadaan Peralatan Usahatani

\begin{tabular}{|c|c|c|c|r|c|c|r|r|}
\hline \multirow{2}{*}{ Informan } & \multicolumn{3}{|c|}{ Cangkul } & \multicolumn{4}{|c|}{ Cored } \\
\cline { 2 - 9 } & $\begin{array}{l}\text { Jumlah } \\
\text { (unit) }\end{array}$ & $\begin{array}{c}\text { Harga } \\
(\mathrm{Rp})\end{array}$ & $\begin{array}{c}\text { Biaya } \\
(\mathrm{Rp})\end{array}$ & $\begin{array}{c}\text { Penyusutan } \\
\text { (Rp) }\end{array}$ & $\begin{array}{c}\text { Jumlah } \\
\text { (unit) }\end{array}$ & $\begin{array}{c}\text { Harga } \\
\text { (Rp) }\end{array}$ & $\begin{array}{c}\text { Biaya } \\
(\mathrm{Rp})\end{array}$ & $\begin{array}{c}\text { Penyusutan } \\
(\mathrm{Rp})\end{array}$ \\
\hline 1 & 1 & 45,000 & 45,000 & 1,875 & 1 & 15,000 & 15,000 & 625 \\
\hline 2 & 1 & 45,000 & 45,000 & 1,875 & 1 & 15,000 & 15,000 & 625 \\
\hline 3 & 1 & 45,000 & 45,000 & 1,875 & 1 & 15,000 & 15,000 & 625 \\
\hline 4 & 1 & 45,000 & 45,000 & 1,875 & 1 & 15,000 & 15,000 & 625 \\
\hline 5 & 1 & 45,000 & 45,000 & 1,875 & 1 & 15,000 & 15,000 & 625 \\
\hline 6 & 1 & 45,000 & 45,000 & 1,875 & 1 & 15,000 & 15,000 & 625 \\
\hline Jumlah & $\mathbf{6}$ & & $\mathbf{2 7 0 , 0 0 0}$ & $\mathbf{1 1 , 2 5 0}$ & $\mathbf{6}$ & & $\mathbf{9 0 , 0 0 0}$ & $\mathbf{3 , 7 5 0}$ \\
\hline
\end{tabular}

5. Pengadaan Kemasan Plastik dan Tali Ikat

Untuk pengemasan Pakcoy Organik yang sudah dipanen menggunakan kemasan plastik dan tali pengikat yang sudah diberi label organik. Untuk 1 kilogram Pakcoy menggunakan kemasan plastik yang telah berlabel organik $1 \mathrm{pc}$ dengan harga Rp 500/pc. 
Jumlah kemasan plastik yang digunakan permusim tanam adalah 1.117 pcs dengan besar biaya yang dikeluarkan adalah Rp 446.800/musim tanam. Sedangkan 1 tali ikat digunakan untuk mengikat Pakcoy dengan berat 0,5/ikat Pakcoy dengan harga tali ikat Rp 200/pc. Total tali ikat yang digunakan untuk satu musim tanam adalah 633 pcs dengan total biaya yang dikeluarkan adalah $\mathrm{Rp}$ 126.600/musim tanam. Untuk rincian pengadaan kemasan plastik dan tali ikat dapat dilihat pada Tabel 5.

Tabel 5. Pengadaan Kemasan Plastik dan Tali Ikat Per Musim Tanam

\begin{tabular}{|c|r|r|r|r|r|r|}
\hline \multirow{2}{*}{ Informan } & \multicolumn{3}{|c|}{ Kemasan Plastik } & \multicolumn{3}{c|}{ Tali Ikat } \\
\cline { 2 - 7 } & $\begin{array}{c}\text { Jumlah } \\
(\mathrm{Pcs})\end{array}$ & $\begin{array}{c}\text { Harga } \\
(\mathrm{Rp})\end{array}$ & \multicolumn{1}{c|}{ Biaya } & $\begin{array}{c}\text { Jumlah } \\
(\mathrm{Pcs})\end{array}$ & $\begin{array}{c}\text { Harga } \\
(\mathrm{Rp})\end{array}$ & Biaya \\
\hline 1 & 97 & 400 & 38,800 & 23 & 200 & 4,600 \\
\hline 2 & - & 400 & - & 610 & 200 & 122,000 \\
\hline 3 & 79 & 400 & 31,600 & - & 200 & - \\
\hline 4 & 198 & 400 & 79,200 & - & 200 & - \\
\hline 5 & 495 & 400 & 198,000 & - & 200 & - \\
\hline 6 & 248 & 400 & 99,200 & - & 200 & - \\
\hline Jumlah & 1,117 & & 446,800 & 633 & & 126,600 \\
\hline Rata-rata & 186.17 & & $74,466.67$ & 105.50 & & 21,100 \\
\hline
\end{tabular}

B. Penggunaan Faktor Produksi

Faktor produksi pertanian atau faktor-faktor yang bekerja dalam usahatani di Kelompok Tani Saung Organik adalah faktor lahan, faktor tenaga kerja, dan faktor modal.

1. Lahan

Luas lahan garapan dalam penelitian ini adalah luas lahan yang diusahakan oleh Kelompok Tani Saung Organik untuk usahatani Pakcoy Organik. Besar kecilnya pendapatan informan dari usahataninya ditentukan oleh luas lahan garapannya. Di samping itu, menurut Wati dkk. (2020), faktor lain yang juga turut mempengaruhi antara lain: kesuburan tanah, penerapan teknologi, harga jual, dan komoditas yang diusahakan. Luas lahan yang dimiliki oleh Kelompok Tani Saung Organik adalah 0,57 hektar dengan status lahan milik sendiri. Sedangkan total luas lahan yang digunakan untuk usahatani Pakcoy Organik di Kelompok Tani Saung Organik adalah 0,5 hektar atau $5040 \mathrm{~m}^{2}$. Proporsi lahan untuk usahatani Pakcoy Organik setiap anggotanya berbeda sesuai kepemilikan lahan. Total jumlah biaya pajak lahan Kelompok Tani Saung Organik untuk lahan produksi Pakcoy Organik adalah Rp 66.500/tahun. Rincian penggunaan lahan usahatani Pakcoy Organik dapat dilihat pada Tabel 6.

Tabel 6. Luas Lahan Petani Pakcoy Organik di Kelompok Tani Saung Organik

\begin{tabular}{|c|r|r|r|c|}
\hline Informan & $\begin{array}{c}\text { Luas Lahan } \\
\left(\mathbf{m}^{2}\right)\end{array}$ & $\begin{array}{c}\text { Luas Lahan } \\
\text { Pakcoy } \\
\text { Organik (m²) }\end{array}$ & $\begin{array}{c}\text { Pajak Lahan } \\
\left(\mathbf{R} / \mathbf{m}^{2} / \text { Musim }\right. \\
\text { tanam })\end{array}$ & $\begin{array}{c}\text { Status } \\
\text { Lahan }\end{array}$ \\
\hline 1 & 420 & 420 & 1.10 & Milik Sendiri \\
\hline 2 & 1,470 & 1,120 & 1.10 & Milik Sendiri \\
\hline 3 & 280 & 280 & 1.10 & Milik Sendiri \\
\hline 4 & 700 & 700 & 1.10 & Milik Sendiri \\
\hline 5 & 1,990 & 1,680 & 1.10 & Milik Sendiri \\
\hline 6 & 840 & 840 & 1.10 & Milik Sendiri \\
\hline Jumlah & $\mathbf{5 , 7 0 0}$ & $\mathbf{5 , 0 4 0}$ & & \\
\hline & & & & \\
\hline
\end{tabular}

Lahan yang dimiliki oleh anggota Kelompok Tani Saung Organik terpencar, tetapi tidak berjauhan. Lahan yang dimiliki tidak berada dekat dengan lahan 
pertanian konvensional, tetapi berada di sekitar hutan. Jarak lahan informan dengan petani atau masyarakat di luar kelompok tani adalah \pm 30 meter, dan dibatasi dengan pagar yang diberi jaring dan tanaman jarak pagar ataupun rumput liar. Kepemilikan lahan terpisah-pisah ini disebabkan oleh kepemilikan tanah anggota Kelompok Tani Saung Organik, namun masih berdekatan dengan anggota lainnya.

Lahan yang digunakan untuk usahatani Pakcoy Organik pada umumnya adalah lahan yang baru dibuka dan sebelumnya belum pernah diusahakan untuk usahatani. Walaupun demikian, Kelompok Tani Saung Organik tetap melakukan konversi lahan sebelum menanam Pakcoy Organik sesuai dengan Standar Nasional Indonesia 6729 : 2013 tentang sistem pertanian organik. Selama masa konversi, lahan yang terkontaminasi oleh bahan-bahan kimia seperti sampah anorganik dan lainnya dihilangkan dari permukaan dan sekeliling lahan. Tanah juga dicangkul, sehingga tanah akan tercampur dan akan mengembalikan unsur hara tanah.

\section{Tenaga Kerja}

Tenaga kerja merupakan korbanan bagi suatu usahatani, sebab tenaga kerja turut mempengaruhi hasil usahatani
(Amelia dkk., 2020). Tenaga kerja pada usahatani Pakcoy Organik di Kelompok Tani Saung Organik adalah anggotanya sendiri sehingga tidak melakukan perekrutan tenaga kerja di luar anggota. Perekrutan tenaga kerja di luar anggota tidak dilakukan karena setiap kegiatan proses budidaya Pakcoy Organik bisa dilakukan secara mandiri oleh anggota Kelompok Tani Saung Organik. Dengan tidak adanya perekrutan tenaga kerja di luar anggota maka kelompok tani tidak mengeluarkan upah untuk membayar tenaga kerja. Untuk tingkat pendidikan anggota Kelompok Tani Saung Organik yang memproduksi Pakcoy Organik dapat dilihat pada Tabel 7.

Tabel 7. Tingkat Pendidikan Petani Pakcoy Organik

\begin{tabular}{clcl}
\hline No & \multicolumn{1}{c}{ Nama } & $\begin{array}{c}\text { Tingkat } \\
\text { Pendidikan }\end{array}$ & Keterangan \\
\hline 1. & Agus & SD & Informan 1 \\
2. & Dadang & SD & Informan 2 \\
3. & Usep & SMA & Informan 3 \\
4. & Imam & SMA & Informan 4 \\
5. & Furqon & S1 & Informan 5 \\
6. & Ita Suherman & S1 & Informan 6 \\
\hline
\end{tabular}

\section{Modal}

Informan memperoleh modal dari berbagai sumber, diantaranya berasal dari uang pribadi, pinjaman dari lembaga kredit, baik resmi seperti bank maupun tidak resmi seperti keluarga, tetangga, tengkulak dan lain-lain, serta modal 
berasal dari bantuan pemerintah ataupun swasta (Rodjak, 2006).

Modal yang diperlukan untuk satu musim tanam untuk lahan seluas 0,5 hektar adalah Rp 3.690.744, para anggota Kelompok Tani Saung Organik memperoleh modal dari milik pribadi. Sampai saat ini sudah ada bantuan dari pihak pemerintah bagi pengembangan usaha berupa bantuan dana untuk sertifikasi lahan dan bantuan bibit pakcoy organik dan sayuran lainnya. Bantuan langsung diberikan oleh pemerintah kepada kelompok tani, dan kelompok tani yang membagikan ke petani untuk digunakan. Dengan adanya bantuan dari pemerintah, menjadi peluang bagi pengembangan usahatani Pakcoy Organik. Untuk rinciannya dapat dilihat pada Tabel 8.

Tabel 8. Tingkat Pendidikan Petani Pakcoy Organik

\begin{tabular}{|c|r|r|l|}
\hline Informan & Luas Lahan $\left(\mathrm{m}^{2}\right)$ & Modal $(\mathrm{Rp})$ & \multicolumn{1}{|c|}{ Sumber } \\
\hline 1 & 420 & 436,137 & Milik Sendiri \\
\hline 2 & 1,120 & 726,532 & Milik Sendiri \\
\hline 3 & 280 & 381,858 & Milik Sendiri \\
\hline 4 & 700 & 556,195 & Milik Sendiri \\
\hline 5 & 1,680 & 971,498 & Milik Sendiri \\
\hline 6 & 840 & 618,524 & Milik Sendiri \\
\hline Jumlah & $\mathbf{5 , 0 4 0}$ & $\mathbf{3 , 6 9 0 , 7 4 4}$ & \\
\hline
\end{tabular}

Berdasarkan Tabel 8 dapat dilihat jumlah modal yang dimiliki tiap informan berbeda tergantung dengan luas lahan yang dimiliki. Semakin luas lahan yang dimiliki maka semakin besar pula modal yang dikeluarkan.

\section{Subsistem Produksi}

Dalam melaksanakan proses produksi, Kelompok Tani Saung Organik mengacu pada SOP (Standard Operating Procedure) yang telah ditentukan dan dibuat dalam panduan ICS (Internal Control System) sehingga semua anggota Kelompok Tani Saung Organik yang memproduksi Pakcoy Organik wajib melaksanakannya. Dengan adanya kewajiban untuk mematuhi SOP maka setiap kegiatan proses produksi informan untuk produksi Pakcoy adalah sama. ICS merupakan sistem penjamin mutu yang terdokumentasi, yang memperkenankan lembaga sertifikasi mendelegasikan inspeksi tahunan semua anggota kelompok secara individual kepada lembaga/unit dari operator yang telah disertifikasi. Dalam prakteknya, secara prinsip poktan melakukan sendiri pengawasan bagi seluruh petani terhadap kesesuaian aturan produksi organis seperti prosedur yang telah ditentukan (Ponisa, 2011).

SOP yang berada dalam panduan ICS ini mengacu pada standar LSPO Inofice yang telah ditentukan. SOP pada LSPO Inofice mengacu pada Standar Nasional Indonesia (SNI) Sistem Pangan 
Organik 01-6729-2013. SNI Sistem

Pangan Organik ini dibuat dengan mengacu pada standar CAC/GL 32-1999 Rev.1-2001, Rev.2-2007 dan IFOAM Basic standard for organic production and processing 2005.

Pada proses budidaya ini Kelompok Tani Saung Organik menggunakan sistem pola tanam dengan menanam 15 hari sekali, sistem ini digunakan untuk memenuhi permintaan agar permintaan tersebut dapat terpenuhi. Dalam proses budidaya ini dilakukannya sistem monokultur. Satu musim tanam untuk tanaman Pakcoy Organik yaitu 30-33 hari atau sekitar 1 bulan, sehingga dalam 1 tahun Kelompok Tani Saung Organik mampu melakukan 12 kali musim tanam. Proses budidaya tersebut sebagai berikut.

\section{A. Penyemaian}

Meskipun benih Pakcoy yang telah tersertifikasi organik masih sangat sulit didapatkan di pasaran, namun petani masih dapat menggunakan bibit atau benih tanpa perlakuan atau telah mendapat perlakuan dengan bahan-bahan yang tidak dilarang dalam SOP. Untuk mencegah adanya zat-zat yang menempel pada benih, sebelum digunakan benih tersebut dapat dicuci menggunakan air hangat terlebih dahulu.

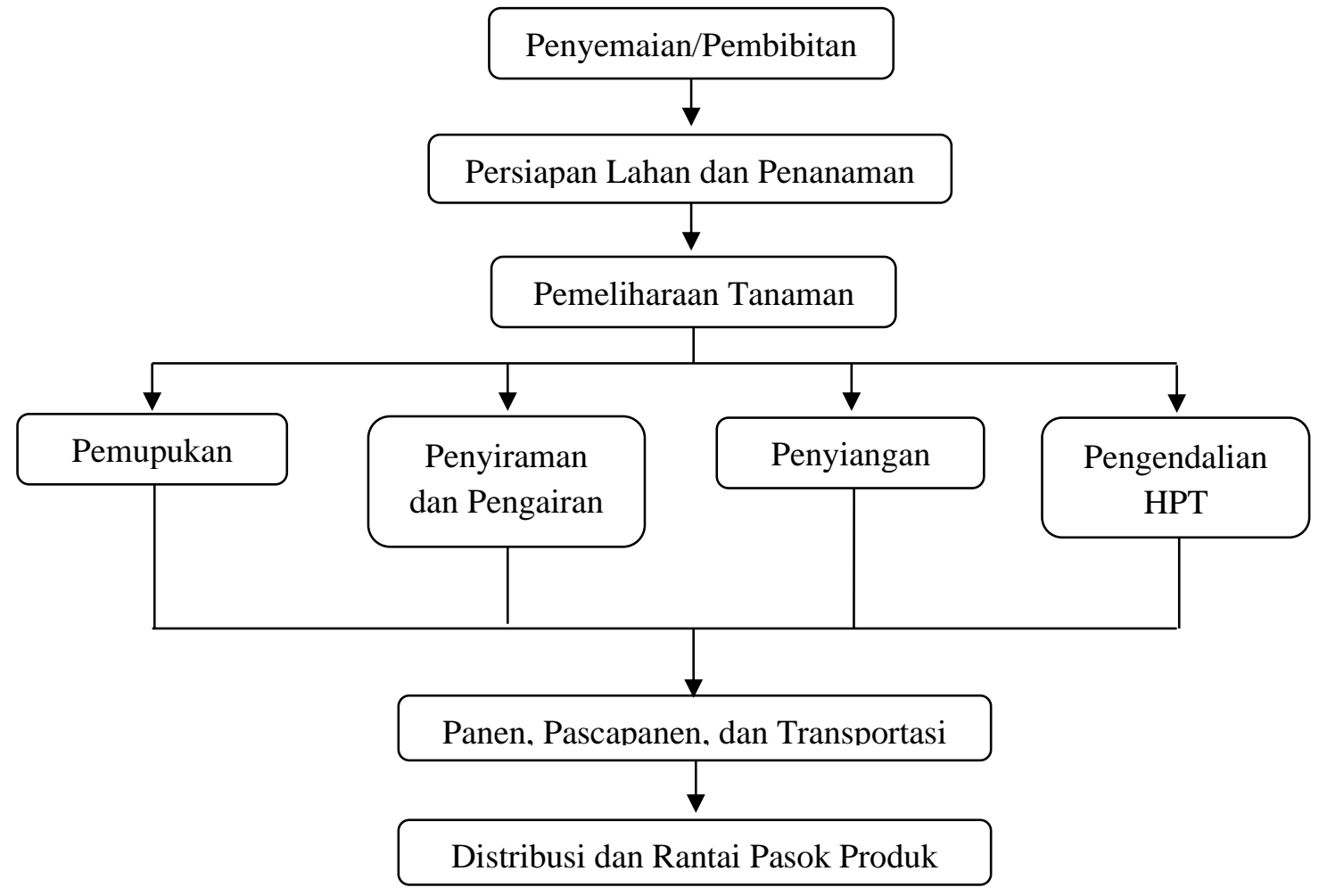

Gambar 1. Proses Produksi Sayuran Organik Kelompok Tani Saung Organik 
Proses penyemaian dalam proses produksi Pakcoy Organik itu sangat penting, karena untuk menghasilkan produk yang baik, maka proses penyemaian harus dilakukan dengan baik dan cermat. Untuk penanaman benih dapat dilakukan langsung pada bedengan penanaman yang telah disiram dan dipupuk dulu sebelumnya. Sebelum ditanam, benih tanaman Pakcoy perlu melalui proses penyemaian terlebih dahulu di lahan khusus. Penyemaian dilakukan selama satu minggu untuk mendapatkan bibit yang baik sebelum dipindahkan ke lahan tanamnya. Benih yang baik, biasanya akan tumbuh setelah 3-5 hari. Setelah itu bibit dapat dipindah ke bedengan penanaman yang telah disiapkan.

\section{B. Persiapan Lahan}

Lahan yang akan ditanami dengan Pakcoy Organik, sebelumnya harus dibersihkan terlebih dahulu dengan cangkul agar lahan menjadi gembur. Lahan yang telah dibersihkan, kemudian dibentuk bedengan-bedengan dengan ukuran lebar 2 x 10 meter, ketinggian bedengan $30-40 \mathrm{~cm}$ dan panjang bedengan disesuaikan dengan luas lahan yang tersedia. Setelah bedengan terbentuk, maka di atas bedengan tersebut ditaburi pupuk kandang secara merata kemudian dicangkul kembali, agar pupuk kandang yang telah ditaburi bercampur dengan tanah. Setelah pemupukan dilakukan, selanjutnya bendengan di siram dengan air agar tanah tidak terlalu kering. Proses persiapan lahan ini menghabiskan waktu $2-3$ hari.

C. Penanaman

Proses penanaman meliputi pemindahan bibit Pakcoy ke bedengan. Dalam proses ini terdapat proses pembuatan lubang tanam, ukuran lebar lubang tanam adalah $4 \times 6 \mathrm{~cm}$ dengan kedalaman $6 \mathrm{~cm}$. Sedangkan untuk jarak tanamnya adalah $20 \times 20 \mathrm{~cm}$. Setelah selesai melakukan proses pembuatan lubang tanam, maka selanjutnya adalah proses penanaman bibit Pakcoy dengan cara memasukan 1 bibit Pakcoy ke 1 lubang tanam lalu ditimbun kembali dengan tanah. Setelah melakukan proses penanaman, tanaman langsung disiram dengan air. Jumlah tanaman yang ditanam dalam 1 bedengan mencapai 100 tanaman.

D. Pemeliharaan

Dalam proses produksi Pakcoy Organik, pemeliharan sayuran organik perlu diperhatikan, agar tanaman tumbuh dengan baik (Rasmikayati dkk., 2020). Pemeliharaan tanaman pada umumnya dilakukan dengan cara manual. 
Pemeliharaan tanaman terdiri atas pemupukan, penyiraman dan pengairan, penyiangan, serta pengendalian hama dan penyakit.

\section{Pemupukan}

Sama halnya penggunaan benih dan bibit yang juga harus sesuai dengan SOP dan syarat yang telah ditentukan oleh LSPO Inofice, untuk penggunaan pupuk pun juga demikian. Petani Saung Organik menggunakan kotoran sapi dan Pupuk Cair Organik. Pupuk kandang yang digunakan tak luput dari pengawasan ICS dan LSPO Inofice, karena salah satu syaratnya adalah sapi tersebut juga harus mengkonsumsi hijauan yang tidak terkontaminasi dengan bahan kimiawi. Sekali produksi (musim tanam) informan Saung Organik rataan menggunakan 2000 kilogram pupuk kandang. Sedangkan pupuk cair organik digunakan sebanyak 0,5 liter dalam satu musim tanam. Pemberian pupuk kandang dilakukan ketika pengolahan tanah dan untuk pupuk cair organik dilakukan hari ke 5 setelah tanam dengan cara disemprotkan langsung ke tanaman Pakcoy.

Sistem pembelian pupuk sendiri yaitu informan mendatangi langsung ke peternak sapi untuk memesan pupuk kandang. Sistem pembayarannya dilakukan setelah pupuk kandang diantar ke lahan. Harga pupuk yang dijual Rp 500/kg ini merupakan harga kompensasi informan kepada peternak, yang terdiri atas upah pengepakan, upah transportasi dan upah angkut pupuk ke lahan.

2. Penyiraman

Informan memiliki luas lahan yang tersertifikasi kurang dari $1 \mathrm{Ha}$ (hektar). Pengairan yang dilakukan oleh petani Saung Organik beragam, ada yang memanfaatkan sumber mata air asli pegunungan, sumur bor, dan memanfaatkan air sungai yang mengalir di sekitar lahan pertanian. Untuk irigasi yang menggunakan air sungai, harus telah mengalami perlakuan untuk mengurangi cemaran, sehingga memenuhi persyaratan baku dan terdokumentasi. Sebelumnya irigasi ini telah ditinjau oleh tim dari LSPO Inofice untuk menentukan, apakah air sungai tersebut bisa digunakan dan tidak mengandung zat-zat kimiawi yang dapat mencemarkan hasil produk organik.

Penyiraman tanaman sangat penting dilakukan, jika pada saat menanam sedang terjadi musim kemarau. Umumnya penyiraman 2 (dua) kali dalam satu hari, yaitu pada pagi hari (pukul 07.00) dan sore hari (pukul 16.00 atau 17.00). Penyiraman dilakukan dengan 
menggunakan alat penyiraman yang biasanya menggunakan gembor dan selang.

\section{Penyiangan}

Penyiangan dilakukan jika terdapat rumput liar (tanaman pengganggu/gulma) ataupun tanaman yang terkena penyakit. Penyiangan dilakukan dengan cara mencabut tanaman penganggu tersebut baik yang berada di luar, ataupun di dalam bedengan serta membuang daun tanaman atau buah tanaman yang terkena penyakit. Penyiangan ini dapat dilakukan setiap dua (2) minggu sekali, atau dilakukan 2-4 kali selama penanaman.

\section{Pengendalian HPT}

Hama yang sering dihadapi oleh petani adalah ulat daun, ulat bulu, kutu daun, dan penyakit yang sering menyerang Pakcoy Organik antara lain penyakit jamur yang disebabkan oleh karat putih, penyakit mati layu dan daun kering. Petani biasanya melakukan pencegahan terhadap hama dengan cara mekanis yaitu mencabut tanaman yang terserang hama. Sedangkan untuk pencegahan penyakit jamur, petani memberikan tricoderma sebelum menanam tanaman Pakcoy Organik. Cara memberikan tricoderma adalah dengan menyemprotkan pada lubang tanam lalu ditutup dengan tanah.

\section{Subsistem Panen dan Pascapanen}

Panen Pakcoy Organik dilakukan setelah sayuran organik telah siap untuk dipanen dan sesuai dengan jadwal panen yang ditentukan oleh pemasok dan konsumen. Pemanenan dilakukan setelah tanaman berumur 30-33 hari, atau jika ada konsumen yang meminta komoditas sayuran mini (baby vegetable), maka waktu panen bisa kurang dari 25 hari. Sehingga Kelompok Tani Saung Organik dapat melakukan produksi sebanyak 12 kali dalam 1 tahun atau memiliki musim tanam sebanyak 12 musim tanam/tahun. Panen dilaksanakan pada pagi dan sore hari. Panen Pakcoy dilakukan dengan cara sayuran langsung dicabut sampai ke akarnya. Setelah dicabut, akar Pakcoy langsung digunting agar tanah yang terbawa tidak banyak. Total jumlah produksi Pakcoy Organik di kelompok tani permusim tanam adalah 1.434 $\mathrm{Kg} / \mathrm{musim}$ tanam dan harga rata-ratanya adalah sebesar Rp 4933/kg. Untuk rinciannya dapat dilihat pada Tabel 9.

Tabel 9. Produksi Pakcoy Organik Per Musim Tanam

\begin{tabular}{|c|r|r|l|r|r|r|}
\hline Informan & $\begin{array}{c}\text { Luas Lahan } \\
\left(\mathrm{m}^{2}\right)\end{array}$ & $\begin{array}{c}\text { Umur } \\
\text { Tanaman }\end{array}$ & Waktu Panen & $\begin{array}{c}\text { Produksi } \\
(\mathrm{Kg})\end{array}$ & $\begin{array}{c}\text { Harga Jual } \\
(\mathrm{Rp})\end{array}$ & $\begin{array}{c}\text { Produktivitas } \\
\left(\mathrm{Kg} / \mathrm{m}^{2}\right)\end{array}$ \\
\hline 1 & 420 & $30-33$ & Pagi dan Sore & 109 & 4,500 & 0.26 \\
\hline 2 & 1,120 & $30-33$ & Pagi dan Sore & 305 & 5,900 & 0.27 \\
\hline 3 & 280 & $30-33$ & Pagi dan Sore & 79 & 4,800 & 0.28 \\
\hline 4 & 700 & $30-33$ & Pagi dan Sore & 198 & 4,800 & 0.28 \\
\hline 5 & 1,680 & $30-33$ & Pagi dan Sore & 495 & 4,800 & 0.29 \\
\hline 6 & 840 & $30-33$ & Pagi dan Sore & 248 & 4,800 & 0.30 \\
\hline Jumlah & $\mathbf{5 0 4 0}$ & & & $\mathbf{1 , 4 3 4}$ & $\mathbf{2 9 , 6 0 0}$ & \\
\hline rata-rata & $\mathbf{8 4 0}$ & & & $\mathbf{2 3 9 . 0 0}$ & $\mathbf{4 , 9 3 3}$ & $\mathbf{0 . 2 8}$ \\
\hline 1 Hektar & $\mathbf{1 0 , 0 0 0}$ & & & $\mathbf{2 , 8 4 6 . 5 0}$ & $\mathbf{4 , 9 3 3 . 3 3}$ & $\mathbf{0 . 2 8}$ \\
\hline
\end{tabular}


Dari Tabel 9 dapat dilihat bahwa setiap informan jumlah produksinya berbeda. Informan yang memiliki produksi yang diatas rata-rata berjumlah 3 orang yaitu inf orman 2, informan 5 , dan informan 6. Sedangkan informan yang memiliki produksi di bawah ratarata adalah informan 1 , informan 3 , dan informan 4. Perbedaan jumlah produksi ini disebabkan oleh perbedaan luas penguasaan lahan, cara penanaman, dan hama penyakit. Sedangkan perbedaan harga disebabkan oleh berbedanya tujuan pasar/konsumen (Deviani dkk., (2019).

Setelah dipanen, penanganan selanjutnya yang dilakukan adalah proses pencucian, penyortiran dan penimbangan produk sesuai dengan pesanan. Pakcoy yang telah dipanen disusun dan diletakkan secara hati-hati di tempat pembersihan yang ada di sekitar kantor kelompok tani. Pembersihan dilakukan dengan cara mencuci sayuran dengan air bersih yang mengalir dan ditiriskan pada tempat penirisan. Setelah pencucian dan penirisan, sayuran akan disortir untuk mendapatkan produk dengan mutu baik sesuai dengan permintaan konsumen maupun pemasok sebelum dikemas. Pakcoy Organik dimasukkan ke dalam kemasan dan diikat dengan tali ikat yang telah diberi stiker berlabel Organik
Indonesia dan nama Kelompok Tani Saung Organik untuk konsumen langsung, dan kemasan plastik putih bening tanpa label untuk pemasok.

Jika proses kemasan tidak segera dilakukan, maka Pakcoy yang telah dicuci dan disortir dapat direndam sementara di dalam air, dengan cara sayuran direndam sebatas akar tanaman agar kesegaran Pakcoy dapat terjaga kesegarannya. Setelah itu Pakcoy harus segera dikemas ke dalam kemasan dan diletakkan secara hati-hati ke dalam kontainer plastik yang sudah dibersihkan terlebih dahulu agar produk Pakcoy tidak mengalami kerusakan dan kontaminasi dari bahan non organik, selanjutnya produk Pakcoy dipasarkan dan diambil langsung ke kantor Kelompok Tani Saung Organik oleh konsumen dan pemasok yang telah melakukan pemesanan.

Berdasarkan prinsip yang terdapat dalam SNI 01-6729-2013 Sistem Pangan Organik, bahwa integritas produk organik harus dipelihara selama penyimpanan dan pengangkutan dengan menggunakan tindakan pencegahan sebagai berikut:

a. Produk organik harus dilindungi setiap saat agar tidak tercampur dengan produk pangan non-organik 
b. Produk organik harus dilindungi setiap saat agar tidak tersentuh bahan yang tidak diizinkan untuk digunakan dalam sistem produksi pangan organik dan penanganannya

c. Penyimpanan produk organik harus dipisahkan dari produk konvensional dan harus secara jelas dicantumkan pada label.

d. Tempat penyimpanan dan kontainer untuk pengankutan harus dibersihkan terlebih dahulu dengan menggunakan bahan yang boleh digunakan agar produk pangan organik tidak terkontaminasi dengan bahan yang dilarang dalam SNI Sistem Pangan Organik.

Proses pengangkutan produk sayuran menggunakan kendaraan yang dipakai oleh konsumen. Konsumen datang langsung ke kantor/pusat produksi Kelompok Tani untuk membeli produk sehingga kelompok tani tidak mengeluarkan biaya untuk distribusi. Berdasarkan Awaliyah dkk. (2020) saluran pemasaran seperti ini termasuk saluran pemasaran yang cukup efisien. Berdasarkan proses penyaluran produk dari produsen sampai ke konsumen akhir, maka saluran pemasaran pakcoy organik di Kelompok Tani Saung Organik dapat dilihat pada Gambar 2.

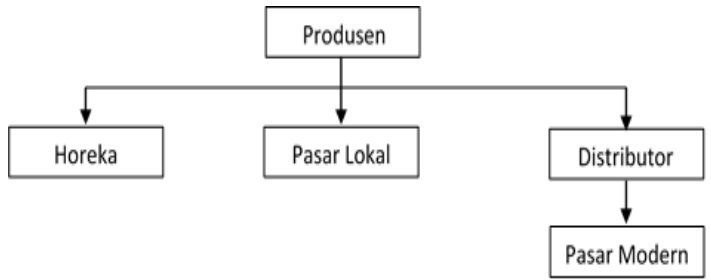

\section{Gambar 2. Saluran Pemasaran Pakcoy Organik}

Konsumen Pakcoy Organik di Kelompok Tani Saung Organik adalah Horeka (Hotel, Kantin, Restoran/Rumah Makan), pasar lokal, dan pasar modern melalui distributor. Persentase penjualan pakcoy organik tiap konsumen berbeda. Persentase horeka sebesar 22,12\%, pasar tradisional sebesar $12,62 \%$, dan pasar modern sebesar 65,26\%. Harga untuk masing-masing konsumen pun berbeda. Horeka membeli Pakcoy mencapai Rp $7.000 / \mathrm{kg}$, pasar modern membeli dengan harga $\mathrm{Rp} 5.500 / \mathrm{kg}$, dan pasar lokal membeli Pakcoy dengan harga Rp 3.700 $-5.000 / \mathrm{kg}$, fluktuatif sesuai dengan harga pasar.

\section{KESIMPULAN}

Keragaan sistem agribisnis pada usahatani pakcoy organik yang dilakukan oleh kelompok tani Saung Organik, yaitu: 1. Pada subsistem hulu, pengadaan sarana produksi oleh kelompok tani Saung Organik meliputi mobil pick up untuk transportasi, cangkul, kored, 
sprayer, pupuk kandang, pupuk cair organik, benih pakcoy gardena, sumur bor untuk memenuhi ketersediaan air, tricoderma, dan kemasan serta tali ikat. Faktor produksi pada kelompok tani Saung Organik meliputi luas total penguasaan lahan di dalam kelompok adalah 0,5 hektar, tidak memakai tenaga kerja di luar anggota kelompok tani, dan jumlah modal yang dimiliki adalah Rp 3.690.744

2. Pada subsistem produksi, proses budidaya dilakukan dengan sistem pola tanam 15 hari sekali dan ditanam secara monokultur. Proses budidaya yang dilakukan adalah penyemaian, persiapan lahan, penanaman, dan pemeliharaan.

3. Pada subsistem panen dan pasca panen, umur panen tanaman pakcoy organik adalah 30-33 hari. Dalam 1 tahun terdapat 12 kali musim tanam dan panen. Produksi pakcoy organik mencapai $1.434 \mathrm{~kg} / \mathrm{musim}$ tanam. Proses pascapanen meliputi pencucian, penyortiran, penimbangan, dan pengemasan. Dalam pemasaran, konsumen yang datang langsung ke kelompok tani untuk mengambil pesanan.

\section{DAFTAR PUSTAKA}

Amelia, N. R. N., Rochdiani, D., \& Saefudin, B. R. (2020). Analisis Pendapatan Usahatani Jambu Biji Varietas Getas Merah Di Desa Panyingkiran, Kecamatan Panyingkiran, Kabupaten Majalengka. Mimbar Agribisnis: Jurnal Pemikiran Masyarakat Ilmiah Berwawasan Agribisnis, 6(2), 754-764.

Awaliyah, F., \& Saefudin, B. R. (2020). Efisisensi Pemasaran Komoditas Mangga Gedong Gincu Di Kabupaten Cirebon. Paradigma Agribisnis, 3(1).

Deviani, F., Rochdiani, D., \& Saefudin, B. R. (2019). Analisis FaktorFaktor yang Mempengaruhi Produksi Usahatani Buncis Di Gabungan Kelompok Tani Lembang Agri Kabupaten Bandung Barat. Agrisocionomics: Jurnal Sosial Ekonomi Pertanian, 3(2), 165-173.

Manuhutu, M. (2005). Berkebun sayuran organik bersama Melly Manuhutu. AgroMedia.

Muchtar, J. (2020). Variasi Pemberian Pupuk Organik Kotoran Sapi dan Ayam terhadap Tanaman Buncis sebagai Upaya Meningkatkan Produktivitas Usahatani Buncis. Agritekh (Jurnal Agribisnis dan Teknologi Pangan), 1(01), 72-95.

Ponisa, T. (2011). Panduan Sistem Kendali Internal. Dinas Tanaman Pangan dan Hortikultura : Garut.

Rachmat, M. (2013). Pembangunan Jangka Menengah Jawa Barat dan Prospek Pengembangan Pertanian Lahan Kering. Jakarta : Badan litbang Pertanian Kementerian Pertanian Republik Indonesia.

Rasmikayati, E., Djuwendah, E., Saefudin, B. R., Syamsiyah, N., \& Ridhatillah, A. (2020). Kajian Pemasaran Relasional Bayam 
Jepang (Horenso) Organik Di Inagreen Farm, Dilema Antara Harapan Dan Kenyataan. Mimbar Agribisnis: Jurnal Pemikiran Masyarakat Ilmiah Berwawasan Agribisnis, 6(1), 365-376.

Rasmikayati, E., Afriyanti, S., \& Saefudin, B. R. (2020). Keragaan, Potensi dan Kendala pada Usaha Kedai Kopi Di Jatinangor: Kasus pada Belike Coffee Shop dan Balad Coffee Works. Agritekh (Jurnal Agribisnis dan Teknologi Pangan), 1(01), 26-45.

Rasmikayati, E., Hapsari, H., \& Saefudin, B. R. (2019). Peningkatan Pengetahuan dan Ketertarikan Remaja pada Hidroponik Berbasis Organik. Jurnal Pengabdian Kepada Masyarakat, 3(6), 147-151.

Rasmikayati, E., Pardian, P., \& Saefudin, B. R. (2020). Penumbuhan Inovasi dan Kreativitas Mahasiswa Unpad dalam Membudidayakan Sayuran Swiss Chard Secara Organik. Jurnal pengabdian kepada masyarakat, 4(1), 15-20.

Rasmikayati, E., Saefudin, B. R., Nadapdap, H. J., \& Awaliyah, F. (2020). Agribusiness Behavior Of Mango Farmers In The District Of Panyingkiran Majalengka Regencybased On Mango Ownership. Sosiohumaniora, 22(2), 206-213.
Rodjak, A. (2006). Manajemen Usahatani. Bandung : Penerbit Pustaka Giratuna.

Sari, Y., Rasmikayati, E., Saefudin, B. R., Karyani, T., \& Wiyono, S. N. (2020, March). Willingness To Pay Konsumen Beras Organik Dan Faktor-Faktor Yang Berkaitan Dengan Kesediaan Konsumen Untuk Membayar Lebih. In Forum Agribisnis (Vol. 10, No. 1, pp. 4657).

Wati, F., Rasmikayati, E., \& Saefudin, B. R. (2020). Analisis Hubungan Karakteristik Anggota Kelompok Tani dengan Penerapan Teknologi Off Season pada Kegiatan Usahatani Mangga di Kecamatan Sedong, Kabupaten Cirebon, Jawa Barat. Jurnal Ekonomi Pertanian dan Agribisnis, 4(4), 715-727.

Yin, R. K. (2013). Studi Kasus, Desain dan Metode Cetakan ke-12, Penerjemah Mudzakir. Raja Grafindo Persada. Jakarta. 